\title{
Pre-metamorphic hydrothermal alteration with gold in a mid-Archaean island arc, Godthåbsfjord, West Greenland
}

\author{
Adam A. Garde, Henrik Stendal and Bo Møller Stensgaard
}

Recently discovered volcaniclastic rocks of andesitic composition form major parts of the mid-Archaean, amphibolite facies supracrustal belts at Qussuk, on Bjørneøen and on part of Storø in western Godthåbsfjord (Fig. 1). These rocks are interpreted as an island arc that represents the onset of the magmatic accretion of the Akia terrane $3070 \mathrm{Ma}$ ago; this terrane is the north-westernmost of several Archaean tectono-stratigraphic terranes in the Nuuk region, which were all amalgamated by $2720 \mathrm{Ma}$ (cf. Hollis et al. 2006). The presence of the arc in the Akia terrane points to similarities between high-grade orthogneiss-amphibolite associations in West Greenland and lower-grade granite-greenstone terrains of other Archaean cratons e.g. in Canada and Western Australia. Volcaniclastic rocks belonging to the ancient arc have been subject to intense synvolcanic, hydrothermal alteration associated with gold-copper mineralisation especially in parts of the Qussuk area. Another important gold prospect occurs on central Storø, which is currently being explored by NunaMinerals A/S (Knudsen et al. 2007 - this volume). This contribution presents new field observations from some of the best preserved parts of the ancient arc at Qussuk and on Bjørneøen, while it remains unclear if the volcano-sedimentary associations and their gold mineralisation at Qussuk, Bjørneøen and the nearby Storø share a common midArchaean geological history.

\section{The age and setting of the ancient arc}

The eastern Akia terrane comprises c. 3060-3000 Ma tonalitic to trondhjemitic orthogneisses, isoclinally folded panels derived from the older andesitic arc, and granites mobilised from the orthogneisses during a late-kinematic thermal event at c. $2980 \mathrm{Ma}$ which also led to granulite facies P-T conditions west of Qussuk and Bjørneøen (Garde 1997, 2007; Garde et al. 2000). Andesitic metavolcanic and volcano-sedimentary rocks were first reported from the eastern Akia terrane by Garde (1997) and Smith (1998). However, volcanic textures are mostly very poorly preserved, and it was not appreciated then, how widespread the andesitic arc is, and that it forms large parts of the supracrustal belts exposed at Qussuk and on Bjørneøen.

Recent age determinations of volcanic zircon grains from central Bjørneøen show that the age of the andesitic arc is $3071 \pm 1 \mathrm{Ma}$ (sample 479827, Garde 2007). The arc is thus marginally older than its orthogneiss host, in agreement with recently observed intrusive contacts into the supracrustal belt (Fig. 2). Similar field relationships in the adjacent Qussuk area further document that the orthogneiss precursors intruded into the arc. However, zircon from volcaniclastic rocks here, on strike with those on Bjørneøen, yields metamorphic ages of 2990-2970 Ma which coincide with the thermal maximum and associated fluid movement; only a few zircon cores approach the true volcanic age of $c .3070 \mathrm{Ma}$

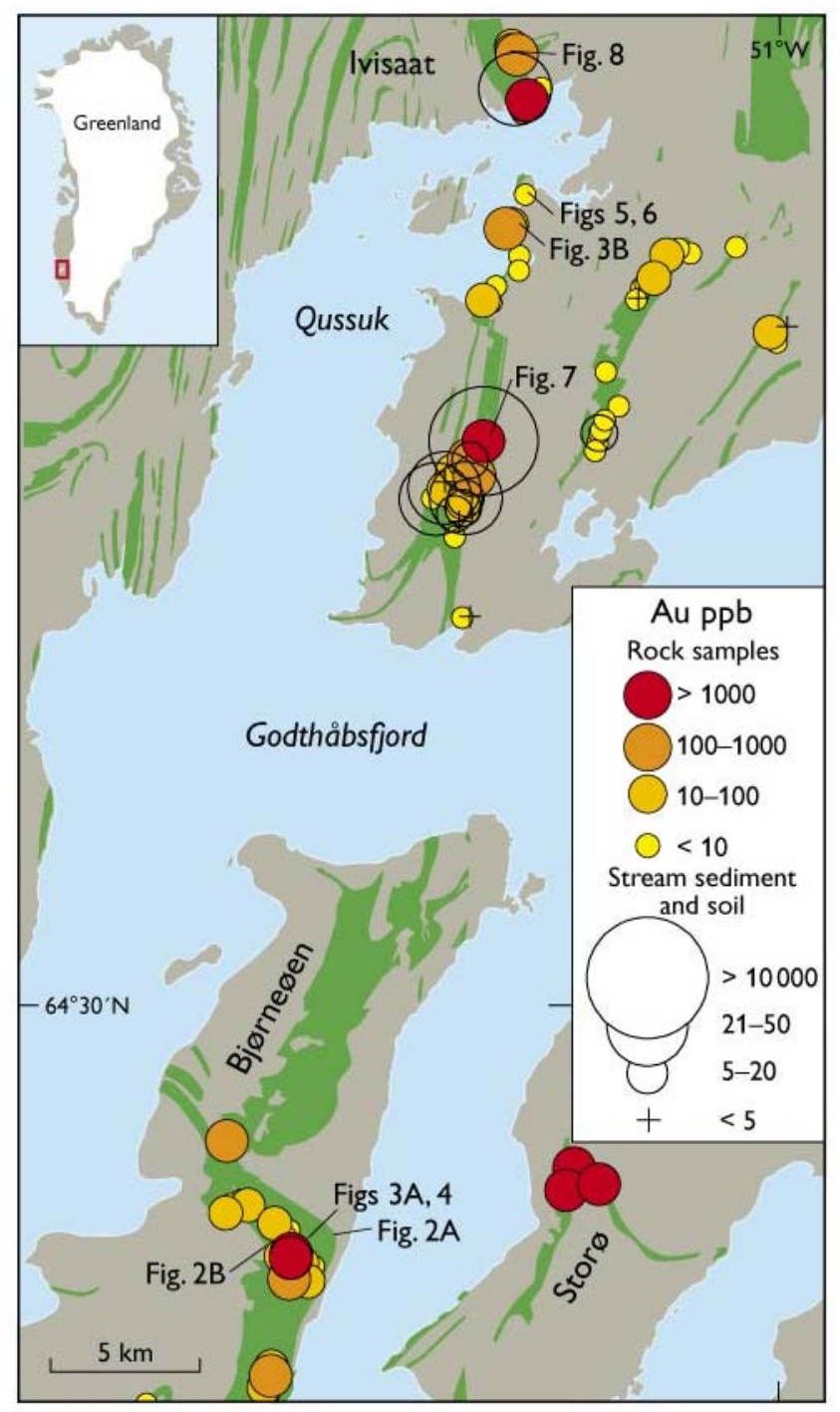

Fig. 1. Simplified map of north-western Godthåbsfjord with supracrustal belts (green), gold anomalies, and locations of Figs 2-8. Modified from Hollis (2005). 

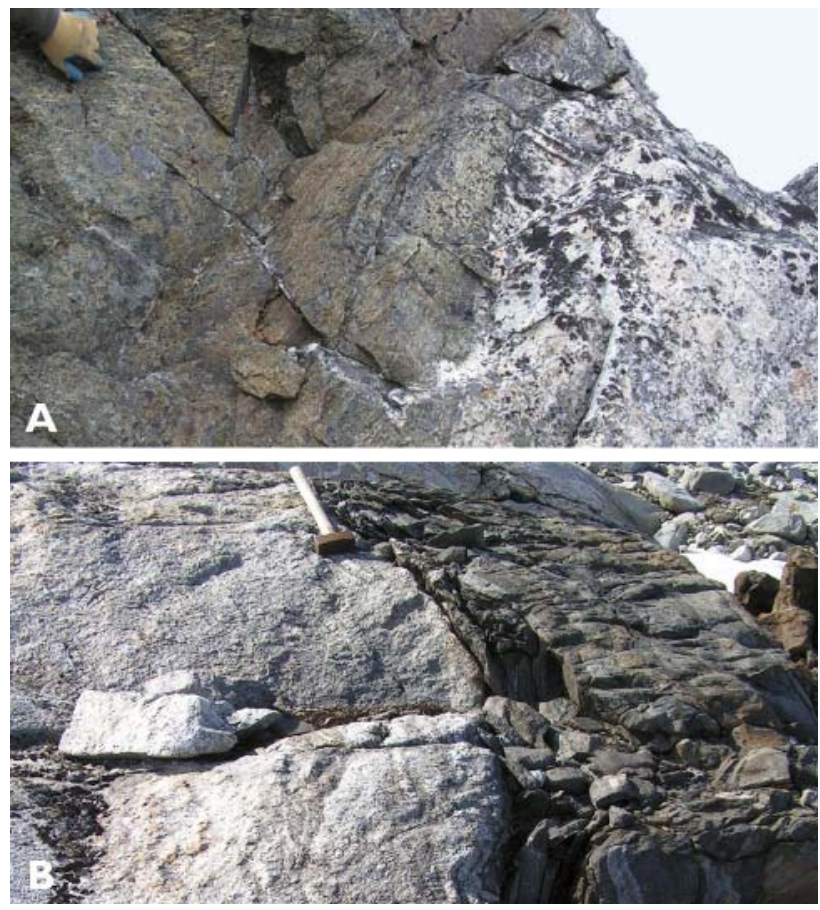

Fig. 2. Intrusive contacts at the footwall (A) and hanging wall (B) of the supracrustal belt on central Bjørneøen (see Fig. 1 for locations).

(Garde 2007). Zircon grains from yet another volcano-sedimentary rock on central Bjørneøen (Fig. 3A) yielded a range of 2908-2742 Ma ages with a cluster around $2825 \mathrm{Ma}$ (sample 479745, Hollis 2005 p. 55). The 2825 Ma cluster was interpreted as the depositional age, and a complex tectonic model for central Bjørneøen was proposed with thrust-stacking of supracrustal rocks and orthogneisses of different ages and origins at the eastern margin of the Akia terrane. However, further field observations in 2006 uncovered that this sample locality lies within the same volcaniclastic sequence as the sample dated at $3071 \mathrm{Ma}$. With the established intrusive contacts of orthogneisses dated at $c$. 3065$3050 \mathrm{Ma}$ (Fig. 2; Hollis 2005 pp. 30-39), this tectonic model is no longer tenable, as the supracrustal belt is older than the orthogneisses and its contacts are not tectonic. Furthermore, a duplicate sample collected at the locality of Fig. 3A by the first author in 2006 yielded a metamorphic U$\mathrm{Pb}$ zircon age of $2986 \pm 3.6 \mathrm{Ma}$ (13 stubby, very indistinctly zoned zircon grains with $\mathrm{Th} / \mathrm{U}<0.01$; unpublished ion probe data, May 2007). Hence, the zircon grains allegedly extracted from sample 479745 seem to have been incorrectly labelled during the sample preparation.

\section{Volcaniclastic and volcano-sedimentary rocks}

The relict volcano-sedimentary arc has been intensely deformed and metamorphosed at middle to upper amphibolite grade and now mostly consists of monotonous, fine-grained, schistose andesitic rocks besides intrusive bodies of mafic-ultramafic rocks. However, small pockets of low-strain rocks with distinct volcaniclastic textures are locally well preserved on central Bjørneøen and in the Qussuk area, particularly in the cores of fold hinges. Andesitic rocks containing volcanic clasts with fiamme textures have been identified on central Bjørneøen and north-eastern Qussuk (Fig. 3), as well as rare, more or less undeformed volcano-sedimentary deposits a few tens of metres across with well-preserved sedimentary structures (Fig. 4). The recognition of the volcaniclastic environments is important, because they document widespread explosive volcanism and hence shallow subaqueous or subaerial volcanic activity in an island arc. Unfortunately, it has not been possible to reconstruct individual volcanic edifices due to the general poor state of preservation.

\section{Synvolcanic hydrothermal alteration}

Hydrothermally altered aluminous and siliceous rocks, commonly associated with disseminated iron sulphides and gold mineralisation, occur in several parts of the relict arc (Hollis 2005; Garde 2007). Unequivocal evidence that the hydrothermal alteration took place in unconsolidated volcaniclastic rocks prior to deformation and metamorphism was found
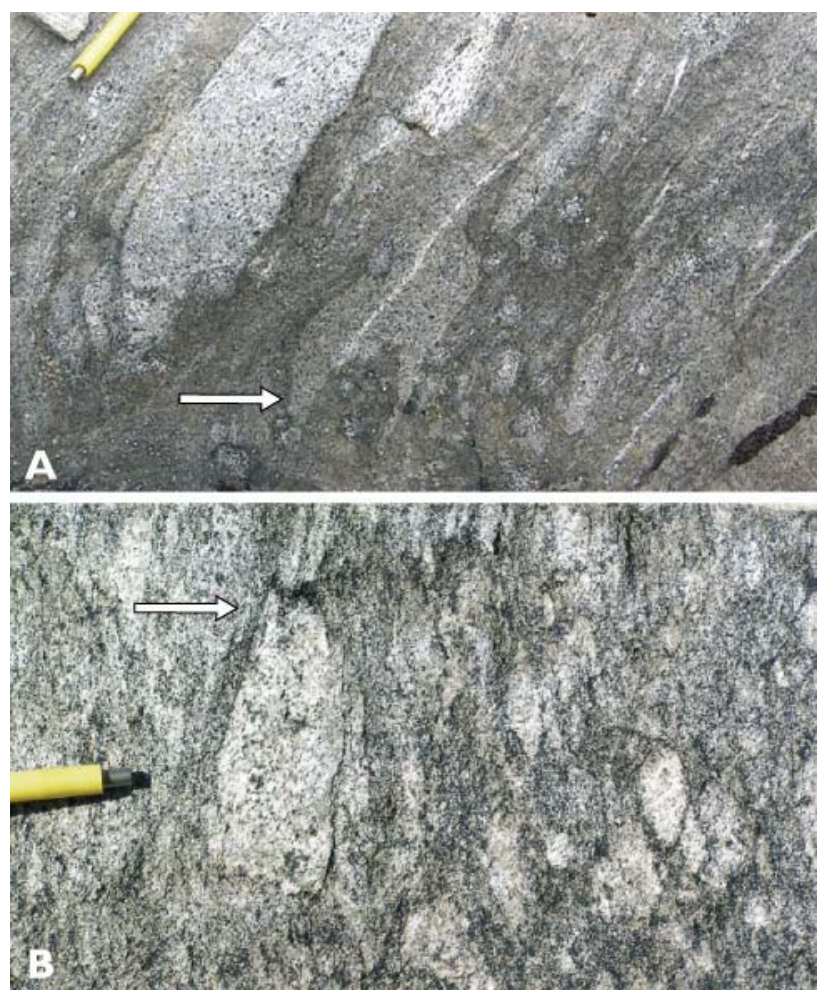

Fig. 3. Volcaniclastic rocks on central Bjørneøen (A) and at north-eastern Qussuk (B) with fiamme textures. Pen $8 \mathrm{~mm}$ thick. For locations see Fig. 1 . 


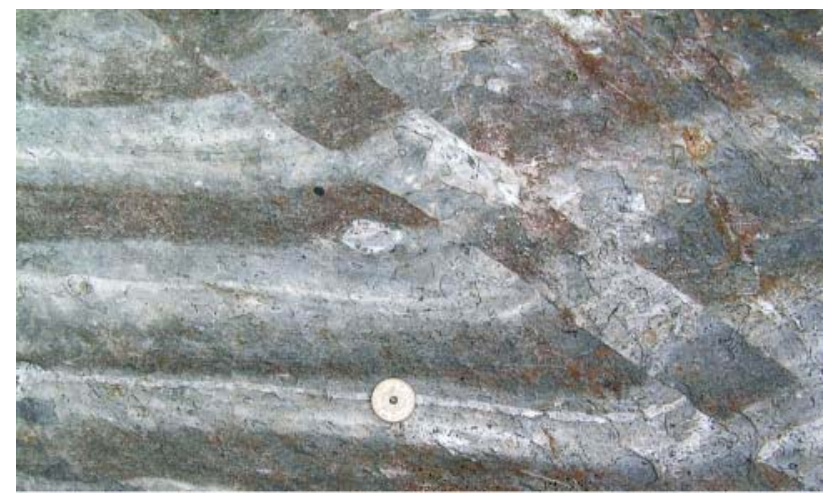

Fig. 4. Graded volcano-sedimentary rock with early brittle/ductile deformation. Central Bjørneøen (see Fig. 1 for location).

in 2006 within the hinge zone of a large fold on the northeastern coast of Qussuk (Fig. 1). The lower part of Fig. 5 displays several nearly undeformed beds of fine- to coarsegrained tuff (or tuffite) with granitic-pegmatitic partial melt veins. The thickest bed displays right way-up graded bedding. The contact to the overlying bed is rusty weathering and contains sporadic iron sulphides and small garnets $(<5 \mathrm{~mm})$, and has clearly been affected by hydrothermal activity. The very localised alteration furthermore indicates that the percolating fluid used the unconsolidated bedding contact as a convenient passageway.

There are many other examples of rocks with more widespread and more intense alteration. Most of these are also intensely deformed and difficult to recognise as hydrothermally altered, but exceptions do occur. Figure 6 shows smooth, grey metatuff hosting an irregular, interfingering, vein-like system of coarser, rusty weathering and crumbling metatuff. This is hydrothermally altered and now contains abundant quartz, biotite, garnet and iron sulphide.
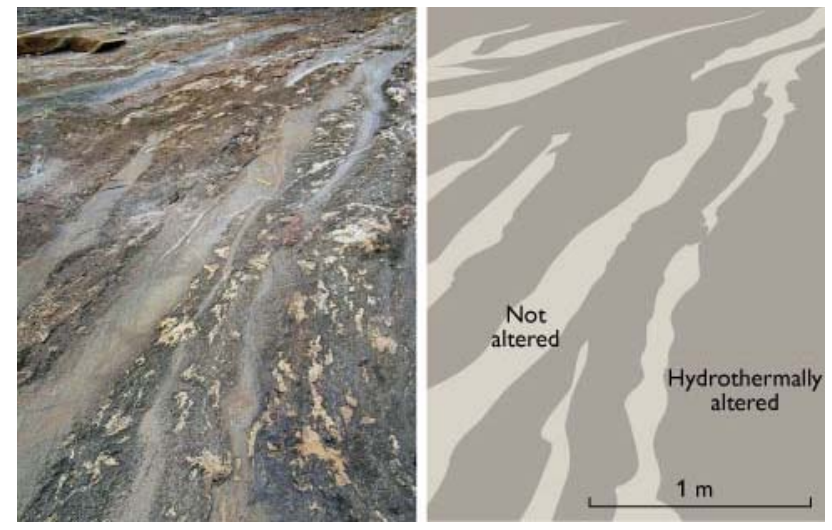

Fig. 6. Interfingering system of early hydrothermal alteration in andesitic (meta)tuff at north-eastern Qussuk (see Fig. 1 for location). Glacial striations have produced a faint oblique 'foliation' visible in the lower left of the exposure.

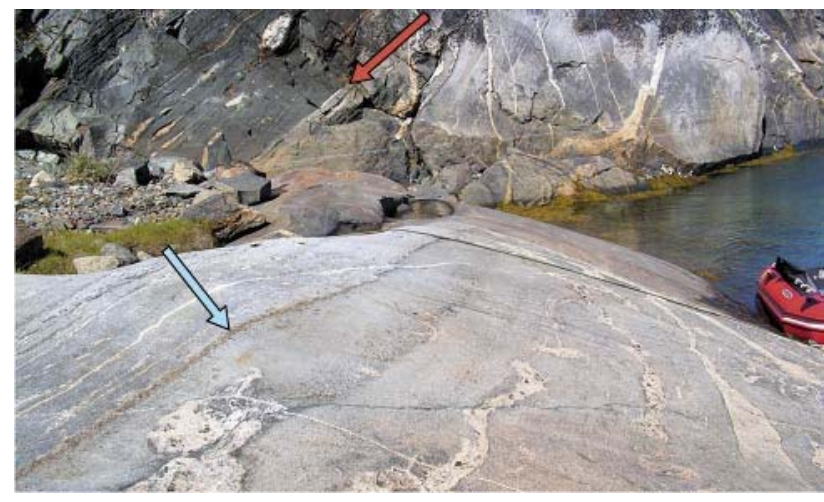

Fig. 5. Bedded metatuff at north-eastern Qussuk (see Fig. 1 for location) showing a primary contact between mafic and intermediate beds (red arrow) and a narrow rusty hydrothermal alteration zone along primary bedding contact (blue arrow).

Rusty weathering and variably gold-mineralised rocks, altered by synvolcanic, hydrothermal fluids and now rich in quartz, biotite, garnet and commonly sillimanite, also occur east and north of Qussuk in tracts up to several kilometres long, which have previously been mapped as aluminous metasedimentary rocks. Figure 7 shows a football-sized enclave of unaltered and undeformed amphibolitic metatuff, which is preserved inside a lens several metres across of garnet-rich rock (hydrothermally altered and metamorphosed tuff). The most intensely altered andesitic rocks now consist of massive sillimanite-fuchsite quartzite, from which most major and trace elements have been leached out except $\mathrm{Si}, \mathrm{Al}$ and $\mathrm{Ti}$, and very immobile elements such as $\mathrm{Ga}, \mathrm{Zr}$ and rareearth elements. Such rocks form the top of Ivisaat mountain north of Qussuk (Fig. 8), where they form a layer c. 5-10 m thick in the core of an isoclinal fold, surrounded by garnetrich and sulphidic, less altered andesitic metavolcanic rocks with widespread gold mineralisation in the ppb range (the authors' unpublished data). This very specific type of hydro-

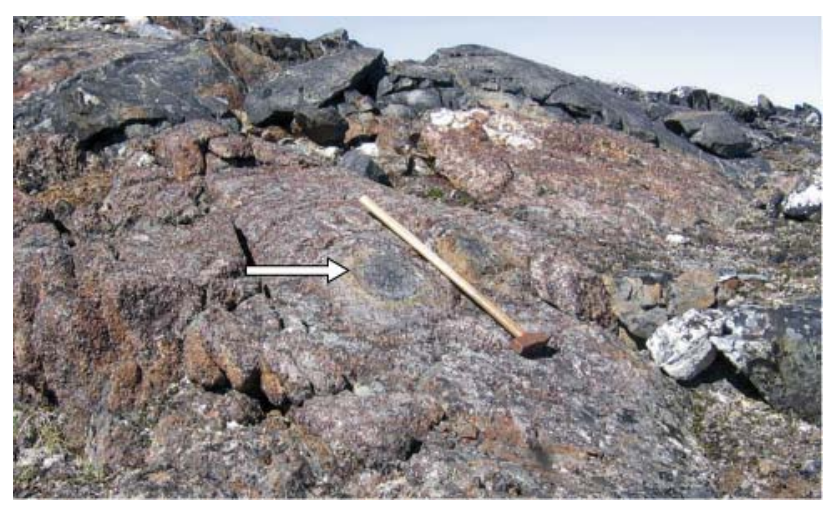

Fig. 7. Enclave of unaltered and undeformed metavolcanic amphibolite (arrow), surrounded by a lens of hydrothermally altered, now garnetrich rock of similar origin. Peninsula east of Qussuk (see Fig. 1 for location). Hammershaft is $c .85 \mathrm{~cm}$ long 


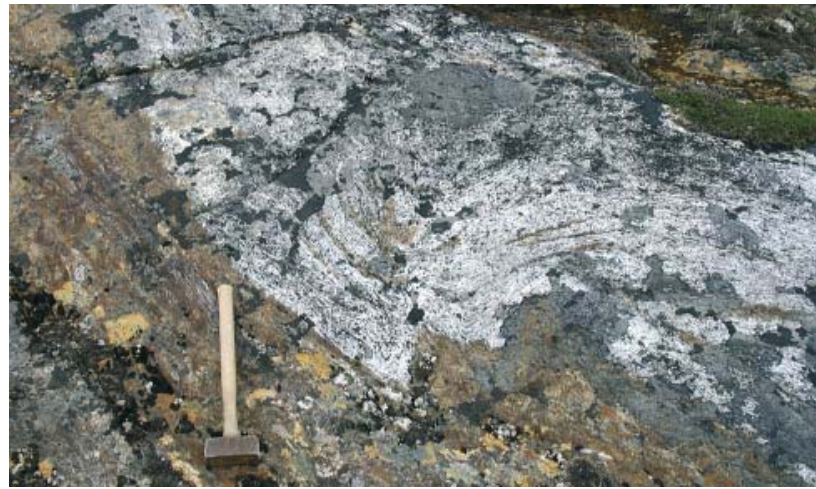

Fig. 8. Folded sillimanite-fuchsite quartzite with disseminated iron sulphides, an intensely hydrothermally altered and metamorphosed rock of andesitic origin. Ivisaat mountain north of Qussuk (see Fig. 1 for location). Hammershaft is c. $45 \mathrm{~cm}$ long.

thermal alteration points to acid leaching under low pressure, a process which is very characteristic of epithermal, high-level hydrothermal systems in modern andesitic arcs, which are commonly associated with gold and copper mineralisation (e.g. Sillitoe \& Hedenquist 2003). A low-pressure hydrothermal system such as found today near the tops of andesitic arcs is a prerequisite for wholesale leaching by strong acids, because higher pressures prevent the dissociation of their hydrogen ions (Sillitoe \& Hedenquist 2003).

\section{Conclusions}

The c. $3070 \mathrm{Ma}$ andesitic arc in the eastern Akia terrane and its slightly younger intrusive counterparts of tonalitic orthogneisses, combined with previous structural evidence of early crustal shortening in most of the Akia terrane, point to the existence of a convergent plate-tectonic system in the North Atlantic craton, where subduction of oceanic crust and partial melting of the subducted slab occurred at least $3070 \mathrm{Ma}$ ago. The identification of the arc complex substantiates previous ideas that the orthogneisses in the Akia terrane are products of slab melting in a convergent plate-tectonic setting. In a wider context this also implies that the typical Archaean high-grade orthogneiss-amphibolite associations in
West Greenland may not represent plate-tectonic environments distinct from the granite-greenstone associations found in most other Archaean cratons, but simply expose deeper sections of the same convergent systems.

The relict arc hosts widespread hydrothermally altered rocks and associated gold (-copper) mineralisation. Newly discovered field relationships show that the hydrothermal systems predated deformation and metamorphism. Furthermore, the peculiar mineralogical composition of the altered rocks combined with their gold mineralisation suggest that the hydrothermal alteration was synvolcanic and epithermal, and characteristic of the arc itself.

\section{References}

Garde, A.A. 1997: Accretion and evolution of an Archaean high-grade grey gneiss-amphibolite complex: the Fiskefjord area, southern West Greenland. Geology of Greenland Survey Bulletin 177, 114 pp.

Garde, A.A. 2007: A mid-Archaean island arc complex in the eastern Akia terrane, Godthåbsfjord, southern West Greenland. Journal of the Geological Society (London) 164, 565-579.

Garde, A.A., Friend, C.R.L., Nutman, A.P. \& Marker, M. 2000: Rapid maturation and stabilisation of middle Archaean continental crust: the Akia terrane, southern West Greenland. Bulletin of the Geological Society of Denmark 47, 1-27.

Hollis, J.A. (ed.) 2005: Greenstone belts in the central Godthåbsfjord region, southern West Greenland: Geochemistry, geochronology and petrography arising from 2004 field work, and digital map data. Danmarks og Grønlands Geologiske Undersøgelse Rapport 2005/42, $215 \mathrm{pp}$.

Hollis, J.A., Frei, D., van Gool, J.A.M., Garde, A.A. \& Persson, M. 2006: Using zircon geochronology to resolve the Archaean geology of southern West Greenland. Geological Survey of Denmark and Greenland Bulletin 10, 49-52.

Knudsen, C., van Gool, J.A.M., Østergaard, C., Hollis, J.A., RinkJørgensen, M., Persson, M \& Szilas, K. 2007: Gold hosting supracrustal rocks on Storø, West Greenland: petrogenesis and structural setting. Geological Survey of Denmark and Greenland Bulletin 13, 17-20.

Sillitoe, R.H. \& Hedenquist, J.W. 2003: Linkages between volcanotectonic settings, ore-fluid compositions, and epithermal precious metal deposits. In: Simmons, S.F. \& Graham, I. (eds): Volcanic, geothermal, and ore-forming fluids; rulers and witnesses of processes within the Earth. Society of Economic Geologists Special Publication 10, 315-343. Smith, G.M. 1998: Geology and mineral potential of the Bjørneøen supracrustal belt, Nuukfjord, West Greenland. Unpublished report, Nunaoil A/s, 13 pp. (in archives of Geological Survey of Denmark and Greenland, GEUS Report File 21649).

\section{Author's address}

Geological Survey of Denmark and Greenland, Øster Voldgade 10, DK-1350 Copenhagen K, Denmark. E-mail: aag@geus.dk 